\title{
Crystallization and Preliminary X-ray Characterization of a Soybean Seed Lipoxygenase
} \author{
and Max O. Funk ${ }^{2}$ \\ ${ }^{1}$ Physical Sciences Center \\ Monsanto Company \\ St Louis, MO 63198, U.S.A. \\ ${ }^{2}$ Department of Chemistry \\ University of Toledo \\ Toledo, OH 43606, U.S.A. \\ ${ }^{3}$ Biophysics Research Division \\ Universily of Michigan \\ Ann Arbor, MI 48109, U.S.A.
}

William C. Stallings ${ }^{1}$, Beth A. Kroa ${ }^{2}$, Richard T. Carroll ${ }^{2}$, Anita L. Metzger ${ }^{3}$

(Received 28 August 1989)

\begin{abstract}
An isoenzyme of soybean (Glycine max L. Merrill cv. Provar) lipoxygenase (EC 1.13.11.12) has been crystallized using the vapor diffusion method. Crystals were grown from solutions of the protein $(7 \mathrm{mg} / \mathrm{ml})$ using 10 to $20 \%(\mathrm{w} / \mathrm{v})$ polyethylene glycol 8000 in citrate/ phosphate buffer $(\mathrm{pH} 5 \cdot 7$ ) containing $0.5 \%(\mathrm{w} / \mathrm{v}) n$-octyl- $\beta$-D-glucopyranoside. The crystals reached maximum dimensions of $0.3 \mathrm{~mm} \times 0.2 \mathrm{~mm} \times>2 \mathrm{~mm}$. The enzyme crystallized in space group $C 222$, with unit cell dimensions $a=246 \AA, b=193 \AA$ and $c=75 \AA$. A calculated $V_{m}$ value of $2 \cdot 35 \AA^{3} /$ dalton was obtained assuming two molecules per asymmetric unit. The density of the crystals was found to be $1 \cdot 16 \mathrm{~g} / \mathrm{ml}$, which confirmed the presence of two molecules per asymmetric unit and indicated a solvent content of $47.5 \%$.
\end{abstract}

Lipoxygenase is one of the key enzymes of polyunsaturated fatty acid metabolism. In the mammalian circulatory system, 5-lipoxygenase is responsible for the inaugural step in the biosynthesis of leukotrienes, a family of arachidonic acid metabolites with potent, medically relevant physiological activities (Samuelsson et al., 1987). For example, one group of these compounds, leukotrienes $\mathrm{C}_{4}, \mathrm{D}_{4}$ and $\mathrm{E}_{4}$, has been identified as the slow-reacting substance of anaphylaxis (SRS-A). Another of these compounds, leukotriene $B_{\mathbf{4}}$, is a chemotactic factor for human neutrophils. The lipoxygenase-derived metabolism of arachidonic acid has been identified as an important contributing factor in numerous pathophysiological states for which there is an inflammatory component (Parker, 1987)

Lipoxygenase is present also in plants. While the physiological role of lipoxygenase in plants has not been elucidated fully, there is evidence for its catalytic participation in the biosynthesis of growth regulators and in the biosynthesis of compounds with pest-resistance properties (Vick \& Zimmerman, 1984; Preisig \& Kuc, 1987). The lipoxygenases are particularly abundant in the seeds of legumes, and the enzyme obtained from soybeun seeds has been the most intensively investigated member of this class (Axelrod et al., 1981). The lipoxygenases are large $(80$ to $95 \mathrm{kDa})$ monomeric proteins and, among those investigated so far, all have been found to contain a non-heme iron cofactor in a unique, as yet undefined, ligand environment. The iron cofactor is believed to play an important role in the catalytic mechanism (Corey, 1987), but other features of the protein structure involved in the catalytic function have not been identified. The amino acid residues that comprise the iron-binding site are unknown, as are the residues responsible for substrate binding and catalysis.

The primary structures for several lipoxygenases, as deduced from the corresponding cDNA sequences, are available (Shibata et al., 1987, 1988; Yenofsky et al., 1988; Ealing \& Casey, 1988; Dixon et al., 1988; Matsumoto et al., 1988). Three soybean 
isoenzymes, one enzyme from peas, the human leukocyte lipoxygenase and the enzyme from HL60 cells all share certain elements of amino acid sequence. The possibility that these elements have been evolutionarily conserved because of their importance to the catalytic mechanism has been recognized. For example, it has been postulated that a highly conserved set of five histidine residues might comprise the iron-binding site. This would be consistent with a number of physical measurements on the nature of the iron site in soybean lipoxygenase-1 (Navaratnam et al., 1988). However, recent sitespecific mutagenesis studies of the human 5-lipoxy genase, in which two of the conserved histidine residues were converted to serine, did not result in an inactive enzyme (Funk et al., 1989). Knowledge of the three-dimensional structure of the enzyme will clearly be critical in resolving the important structural details of the protein that are relevant to its mode of action.

Soybean lipoxygenase-1 was first obtained in crystalline form in 1947 (Theorell et al., 1947). In the intervening years, however, crystals of the protein suitable for the determination of threedimensional structure by X-ray diffraction have not been ubtained. Experiments in our laboratory have made available substantial quantities of several highly purified soybean lipoxygenase isoenzymes (Funk et al., 1985). This has provided us with an opportunity to search for conditions for the crystallization of samples of the enzyme in a form suitable for structure determination. While we were unable to obtain well-ordered crystals of lipoxygenase-1, we found that a second isoenzyme could be crystallized in a useful fashion. For reasons that are explained elsewhere, we have come to refer to this isoenzyme as P4 (Draheim et al., 1989). It appears to be the same as the isoenzyme referred to as lipoxygenase-2 by other investigators (Axelrod et al., 1981).

The P4 isoenzyme of soybcan lipoxygenase was isolated as described (Funk et al., 1986). Briefly, the enzyme was extracted from mature dry soybean seeds in buffer containing protease inhibitors. Following ammonium sulfate fractionation (30 to $60 \%$ saturation) and dialysis, the proteins were resolved on a chromatofocusing column equilibrated at $\mathrm{pH} 5.7$ (histidine buffer) and eluted at $\mathrm{pH} 4.5$ (Polybuffer 94). The buffer was exchanged by dialy. sis in 50,000 nominal molecular weight cut-off membranes. The purified enzyme was concentrated in centrifugal concentrators (Centriprep 30 and Centricon 30, Amicon). Conditions for the crystallization were screened using the vapor diffusion technique (McPherson, 1982) in ACA CrystalPlates (Flow Laboratories). Large-scale experiments employed the vapor diffusion technique in concentric beakers. Typically, a sample consisting of $3 \mathrm{ml}$ of $20 \%(\mathrm{w} / \mathrm{v})$ polyethylene glycol (PEG 8000) and $0.2 \%(\mathrm{w} / \mathrm{v})$ sodium azide in McIlvaine's citric acid phosphate buffer (pH 5.7), $1 \mathrm{ml}$ of protein solution (38 to $42 \mathrm{mg} / \mathrm{ml}$ ), $1 \mathrm{ml}$ of distilled deionized water and $1 \mathrm{ml}$ of $3 \%(\mathrm{w} / \mathrm{v}) n$-octyl- $\beta$-D-glucopyranoside was equilibrated against $5 \mathrm{ml}$ of $20 \%$ PEG 8000 .
Formation of erystals was evident in 24 to 72 hours at room temperature. The long crystals continued to thicken over a six to eight week period and attained maximum dimensions of $0.3 \mathrm{~mm} \times 0.2 \mathrm{~mm} \times$ $>2 \mathrm{~mm}$.

The crystals were examined by diffraction techniques using a rotating anode $\mathrm{X}$-ray generator with copper target and graphite monochromator; the instrument was operated with a $0.5 \mathrm{~mm} \times 10 \mathrm{~mm}$ filament at settings of $50 \mathrm{kV}$ and $180 \mathrm{~mA}$. Still and unscreened small-angle precession photographs of the $h 0 l$ and $0 k l$ zones revealed $\mathrm{mmm}$ Laue symmetry and patterns consistent with an orthorhombic $C$-centered unit cell. Lattice constants measured from $8^{\circ}$ zero-level precession photographs were $a=246 \AA, b=193 \AA$ and $c=75 \AA$, and the space group was $C 222_{1}$. A calculated Matthews (1968) coefficient, $V_{\mathrm{m}}$, of $2 \cdot 35 \AA^{3} / \mathrm{Da}$ was obtained assuming a molecular mass of $95 \mathrm{kDa}$ for the protein with two molecules per asymmetric unit $(Z=16)$. The density of the crystals was determined to be $1.16 \mathrm{~g} / \mathrm{cm}^{3}$ using bromobenzene/xylene mixtures; assuming a partial specific protein volume of $0.74 \mathrm{~cm}^{3} / \mathrm{g}$, the respective calculated densities for $Z=8$ and $Z=16$ were 1.09 and $1.18 \mathrm{~g} / \mathrm{cm}^{3}$. The observed value was therefore also consistent with the presence of two molecules per asymmetric unit and indicated that solvent molecules occupied $47.5 \%$ of the lattice volume.

The present crystals of soybean lipoxygenase were elongated along the crystallographic $c$ axis; for example, the length of the single crystal used to record most of the patterns exceeded $3 \mathrm{~mm}$. We plan to exploit this aspect of the habit in data collections, translating fresh volumes of the crystal sample into the beam after exposure of previous regions. At room temperature, the crystals were stable in the $\mathrm{X}$-ray beam for about 24 hours. We have observed diffraction at $3 \cdot 4 \AA$ resolution.

Density measurements have been used to resolve the ambiguity in the number of chain copies per unit cell. While twofold averaging can provide only marginal phasing power, it will certainly be of value in chain tracing and clarification of molecular boundaries. Our next goal will be to obtain a data set from the native crystals at about $6 \AA$ resolution. This level of resolution should be sufficient for the location of heavy-atom binding sites in derivatives and for determination of the non-crystallographic symmetry operations. We anticipate the need to transfer the crystals to other buffers that would offer advantages in the binding of derivatization reagents; crystals also form when the phosphate citrate combination is replaced by $2-(N$-morpholino $)$ ethanesulfonic acid.

Although it may be possible to build a model with side-chains at $3.5 \AA$ resolution when the phases are determined with sufficient accuracy, the current resolution limit is not optimal for the long-term goal of inhibitor design. We may observe diffraction at higher resolution at a synchrotron source, or with larger crystals. The erystallization effort is continuing, directed in part toward obtaining addi- 
tional forms with more order. For example, one prismatic habit has been observed recently.

This research was supported financially by the National Institutes of Health, the National Science Foundation, and the D'Arce Foundation for Medical Research and Development. We are grateful to Martha Ludwig for allowing us to perform the initial crystallization experiments at the Biophysics Research Division of the University of Michigan.

\section{References}

Axelrod, B., Cheesbrough, T. M. \& Laasko, S. (1981) Methods Enzymol. 71, 441-451.

Corey, E. J. (1987). Pure Appl. Chem. 59, 269-278.

Dixon, R. A. F., Jones, R. E., Diehl, R. E., Bennett, C. D., Kargman, S. \& Rouzer, C. A. (1988). Proc. Nat. Acad. Sci., U.S.A. 85, 416-420.

Draheim. J. E., Carroll, R. T., McNemar, T. B., Dunham, W. R., Sands, R. H. \& Funk, M. O. (1989). Arch. Biochem. Biophys. 269, 208-218.

Ealing, P. M. \& Casey, R. (1988). Biochem.J. 253, 915-918.

Funk, M. O., Whitney, M. W., Hausknecht, E. C. \& O'Brien, E. M. (1985). Anal. Biochem. 146, 246-251.

Funk, M. O., Carroll, R. T., Thompson, J. F. \& Dunham, W. R. (1986). Plant Physiol. 82, 1139-1144.
Funk, C. D., Gunne, H., Steiner, H., Izumi, T. \& Samuelsson, B. (1989). Proc. Nat. Acad. Sci., U.S.A 86, 2592-2596.

Matthews, B. W. (1968). J. Mol. Biol. 33, 491-497.

Matsumoto, T., Funk, C. D., Radmark, O., Hoog, J.-O. Jornvall, H. \& Samuelsson, B. (1988). Proc. Nat. Acad. Sci., U.S.A. 85, 26-30.

McPherson, A. (1982). Preparation and Analysis of Protein Crystals, Wiley-Interscience, New York.

Navaratnam, S., Feiters, M. C., Al-Hakim, M., Allen, J. C., Veldink, G. A. \& Vliegenthart, J. F. G. (1988). Biochim. Biophys. Acta, 956, 70-76.

Parker, C. W. (1987). Annu. Rev. Immunol. 5, 65-84.

Preisig, C. L. \& Kuc, J. A. (1987). Plant Physiol. 84 891-894.

Samuelsson, B., Dahlen, S.-E., Lindgren, J. A., Rouzer, C. A. \& Serhan, C. N. (1987). Science, 237, $1171-1176$.

Shibata, D., Steczko, J., Dixon, J. E., Hermodson, M. Yazdanparast, C. \& Axelrod, B. (1987). J. Biol. Chem. 262, 10080-10085.

Shibata, D., Steczko, J., Dixon, J. E., Andrews, P. C., Hermodson, M. \& Axelrod, B. (1988). I. Biol Chem $263,6816-6821$.

'Theorell, H., Akesson, A. \& Holman, R. T. (1947). Acta Chem. Scand. 1, 571-576.

Vick, B. A. \& Zimmerman, D. C. (1984). Plant Physiol. 75, $458-461$.

Yenofsky, R. L., Fine, M. \& Liu, C. (1988). Mol. Gen. Genet. 211, 215-222. 